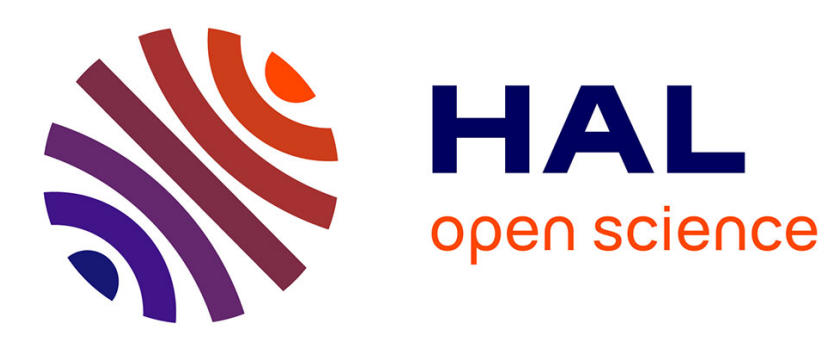

\title{
Biogeography of N 2 Fixation Influenced by the Western Boundary Current Intrusion in the South China Sea
}

Yangyang Lu, Zuozhu Wen, Dalin Shi, Wenfang Lin, Sophie Bonnet, Minhan Dai, Shuh-ji Kao

\section{- To cite this version:}

Yangyang Lu, Zuozhu Wen, Dalin Shi, Wenfang Lin, Sophie Bonnet, et al.. Biogeography of N 2 Fixation Influenced by the Western Boundary Current Intrusion in the South China Sea. Journal of Geophysical Research. Oceans, 2019, 124 (10), pp.6983-6996. 10.1029/2018JC014781 . hal-02461797

\section{HAL Id: hal-02461797 \\ https://hal-amu.archives-ouvertes.fr/hal-02461797}

Submitted on 30 Jan 2020

HAL is a multi-disciplinary open access archive for the deposit and dissemination of scientific research documents, whether they are published or not. The documents may come from teaching and research institutions in France or abroad, or from public or private research centers.
L'archive ouverte pluridisciplinaire HAL, est destinée au dépôt et à la diffusion de documents scientifiques de niveau recherche, publiés ou non, émanant des établissements d'enseignement et de recherche français ou étrangers, des laboratoires publics ou privés. 


\title{
Biogeography of $\mathbf{N}_{2}$ Fixation Influenced by the Western Boundary Current Intrusion in the South China Sea
}

\author{
Yangyang $\mathrm{Lu}^{1,2,3}$, Zuozhu Wen ${ }^{1,4}$, Dalin Shi ${ }^{1,4}$, Wenfang $\operatorname{Lin}^{1,4} \quad$, Sophie Bonnet ${ }^{5}$, \\ Minhan Dai ${ }^{1,3}$, and Shuh Ji Kao ${ }^{1,3}$ \\ ${ }^{1}$ State Key Laboratory of Marine Environmental Science, Xiamen University, Xiamen, China, ${ }^{2}$ Key Laboratory of Marine \\ Ecosystem and Biogeochemistry, State Oceanic Administration \& Second Institute of Oceanography, Ministry of Natural \\ Resources, Hangzhou, China, ${ }^{3}$ College of Ocean and Earth Sciences, Xiamen University, Xiamen, China, ${ }^{4}$ College of the \\ Environment and Ecology, Xiamen University, Xiamen, China, ${ }^{5}$ Aix Marseille Université, CNRS/INSU, Université de \\ Toulon, IRD, Mediterranean Institute of Oceanography (MIO), Marseille, France
}

\begin{abstract}
The $\mathrm{N}_{2}$ fixation and primary production rates were measured simultaneously using ${ }^{15} \mathrm{~N}_{2}$ and ${ }^{13} \mathrm{C}$ incubation assays in the northern South China Sea influenced by the Kuroshio intrusion (KI) seasonally. The degree of KI (KI index, range from 0 to 1 ) was assessed by applying an isopycnal mixing model. The water column integrated $\mathrm{N}_{2}$ fixation and primary production for stations with $\mathrm{KI}$ index larger than 0.5 were $463 \pm 260 \mu \mathrm{mol} \mathrm{N} \cdot \mathrm{m}^{-2} \cdot$ day $^{-1}$ and $62 \pm 19 \mathrm{mmol} \mathrm{C} \cdot \mathrm{m}^{-2} \cdot$ day $^{-1}$, respectively, significantly higher than those for stations with KI index lower than $0.5\left(50 \pm 10 \mu \mathrm{mol} \mathrm{N} \cdot \mathrm{m}^{-2} \cdot \mathrm{day}^{-1}\right.$ and $28 \pm 10 \mathrm{mmol} \mathrm{C} \cdot \mathrm{m}^{-2} \cdot \mathrm{day}^{-1}$, respectively). Trichodesmium was the dominant diazotroph at stations with $\mathrm{KI}$ index larger than 0.5 , with 2 orders of magnitude higher nifH gene abundance than that at stations with $\mathrm{KI}$ index lower than 0.5 . However, the highest $\mathrm{N}_{2}$ fixation rates were found in waters with moderate $\mathrm{KI}$ index around 0.6, suggesting that frontal zone mixing might stimulate $\mathrm{N}_{2}$ fixation. Our results demonstrated that diazotrophs (mainly Trichodesmium) were tightly associated with the KI, which modulated the biogeographic distribution of $\mathrm{N}_{2}$ fixers. In summary, we found the transportation of Trichodesmium by KI, then, we quantified the fraction of KI and $\mathrm{N}_{2}$ fixation rates in the northern South China Sea. The results suggested that KI generated a new biogeographic regime which could significantly influence the carbon and nitrogen cycles far away from the main stream.
\end{abstract}

\section{Introduction}

Biological productivity in the low-latitude oligotrophic ocean is largely limited by bioavailable nitrogen (Moore et al., 2013). In these systems, the nitrate supply from subsurface water is impeded by the permanent thermocline. Thus, $\mathrm{N}_{2}$-fixing organisms (or diazotrophs) that convert inert $\mathrm{N}_{2}$ gas into bioavailable $\mathrm{N}$ sustain the major part of new primary production (Capone et al., 2005).

Trichodesmium is a major diazotrophic cyanobacterium that is widespread in tropical and subtropical oceans (Capone et al., 2005). Annually, around half of the new bioavailable nitrogen introduced by $\mathrm{N}_{2}$ fixation could be attributable to Trichodesmium in the global oceans (Bergman et al., 2013). Previous studies demonstrated that physical processes, such as eddies and currents, might play a vital role in shaping the spatial pattern of Trichodesmium in the ocean (Davis \& McGillicuddy, 2006; Fong et al., 2008; Lipschultz \& Owens, 1996; Olson et al., 2015; Taboada et al., 2010). In the Northern Hemisphere, elevated Trichodesmium abundance is often observed within anticyclone eddies (warm eddy) due to nitrogen limitation but sufficient phosphorus and iron (Davis \& McGillicuddy, 2006; Fong et al., 2008; Olson et al., 2015). In addition, due to the buoyant character of Trichodesmium (Walsby, 1978 and Walsby et al., 1992), the ocean currents are found to spread Trichodesmium widely (Lipschultz \& Owens, 1996; Taboada et al., 2010). However, whether the transported Trichodesmium is active and capable of $\mathrm{N}_{2}$ fixation after the long-distance transportation remains unclear (Lipschultz \& Owens, 1996). Moreover, the quantitative field information on how and to what extent the ocean currents may impact Trichodesmium-derived $\mathrm{N}_{2}$ fixation and its association with primary production is still insufficient. Recently, several Trichodesmium $\mathrm{N}_{2}$ fixation hot spots were discovered around islands, sometimes forming extensive blooms, likely due to iron supply (Berthelot et al., 2017; Bonnet et al., 2017; Dupouy et al., 2011; Shiozaki, Kodama, et al., 2014). If most of the hot spots signals could be transported to remote oceans (Shiozaki et al., 2013), it will reshape the global $\mathrm{N}_{2}$ fixation flux and thus influence the oceanic nitrogen and carbon cycling significantly. 

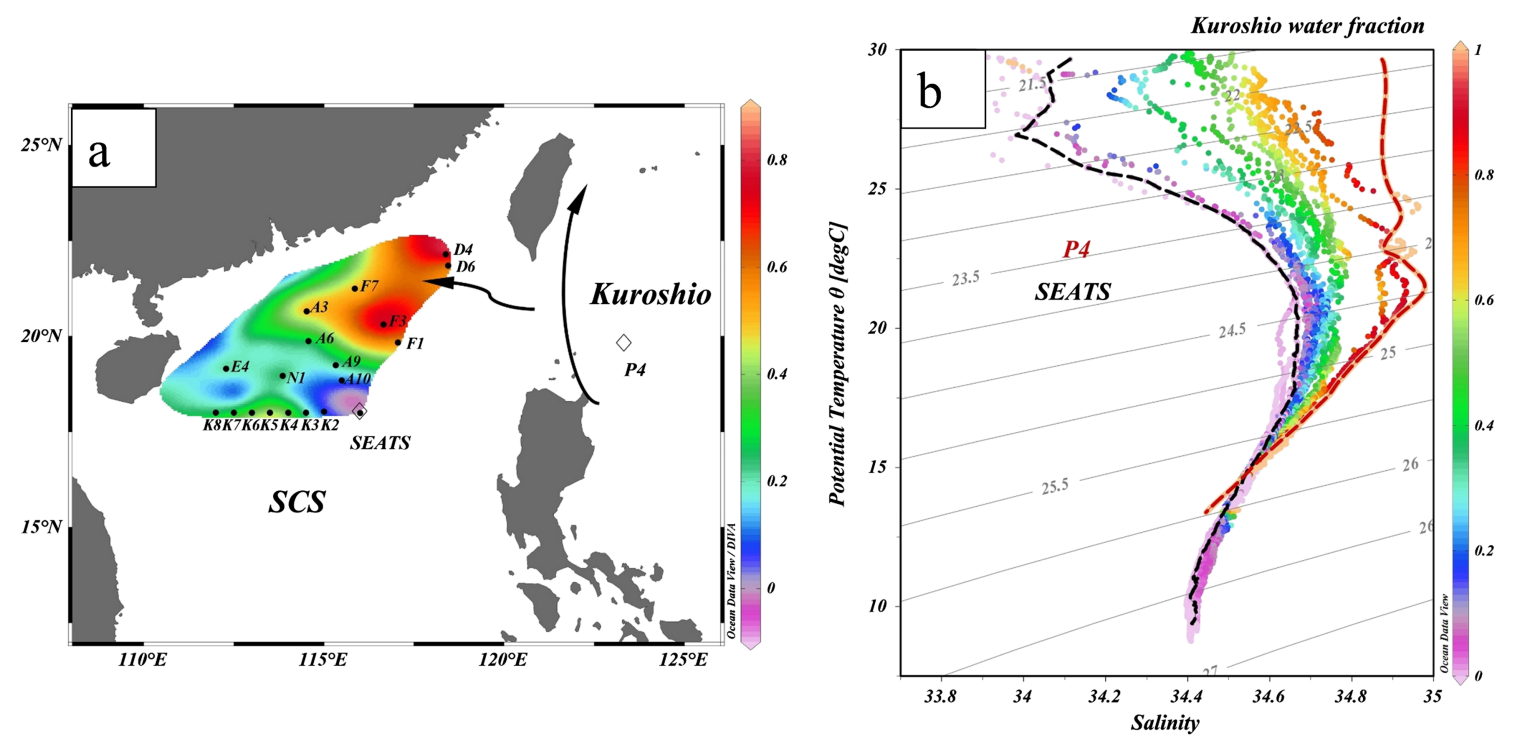

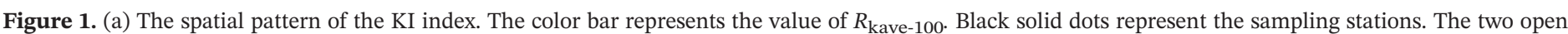
diamonds are the two end member stations (SEATS for the SCS and P4 for the Kuroshio) chosen for the isopycnal mixing model. (b) $\theta-S$ diagram of the upper $400 \mathrm{~m}$ for all the investigated stations. The red dashed curve denotes typical Kuroshio water, and the black dashed curve denotes typical SCS water. KI = Kuroshio intrusion; SCS = South China Sea.

The South China Sea (SCS), the largest marginal sea in the North Pacific, has a low $\mathrm{N}_{2}$ fixation rate and Trichodesmium abundance during the warm season (Lee Chen et al., 2003, 2014). The reported $\mathrm{N}_{2}$ fixation rates (with an average of $51.7 \pm 6.2 \mu \mathrm{mol} \mathrm{N} \cdot \mathrm{m}^{-2}$.day ${ }^{-1}$ ) fall within the lowest range of rates $\left(1-100 \mu \mathrm{mol} \mathrm{N} \cdot \mathrm{m}^{-2} \cdot\right.$ day $^{-1}$ ) in the global $\mathrm{N}_{2}$ fixation database complied by Luo et al. (2012). Such low rates and low Trichodesmium abundances have been attributed to a deficiency of iron and the relatively shallower nitracline in the SCS (Lee Chen et al., 2008; Wu et al., 2003). In contrast, the Kuroshio, a western boundary current to the east of the SCS, is characterized by high $\mathrm{N}_{2}$ fixation rates $\left(\sim 200 \mu \mathrm{mol} \mathrm{N} \cdot \mathrm{m}^{-2} \cdot\right.$ day $\left.^{-1}\right)$ mainly driven by Trichodesmium (Lee Chen et al., 2008, 2014). The Kuroshio intrudes into the SCS through the Luzon Strait seasonally. A previous study showed that the intrusion of nutrient-depleted Kuroshio may act as a diluter to diminish the nutrient stock in the upper water column of the SCS (Du et al., 2013). Meanwhile, the oligotrophic Kuroshio Current brings in dissolved organic carbon-enriched seawater (Wu et al., 2015), which may stimulate nitrification in the frontal zone during mixing (Xu et al., 2018). Presumably, the Kuroshio intrusion also exhibits a distinguished high Trichodesmium abundance and $\mathrm{N}_{2}$ fixation rate in the SCS. This seasonal intrusion phenomenon facilitates a perfect case to investigate how the current could affect the spatial distribution and activity of Trichodesmium and consequently primary production in the euphotic zone in the SCS. Despite its potential significance, such an effect has not yet been explored in Pacific marginal seas. In this paper, we provide a biogeochemical view of the intrusion of a western boundary current into a marginal sea, to advance our knowledge of the coupling of carbon and nitrogen cycling in the euphotic zone of a semiclosed basin.

\section{Materials and Methods}

\subsection{Hydrography and Nutrients}

This study was conducted on board the R/V Dongfanghong 2 in the northern South China Sea (NSCS) from 15 May to 7 July 2016. In order to investigate the potential influence of $\mathrm{KI}$ to $\mathrm{N}_{2}$ fixation, 19 stations were selected from the region close to Luzon Strait to the further west region in the NSCS basin (Figure 1a). At each station, temperature and salinity were recorded by a Seabird 911 CTD. Five to six depths (corresponding to $92 \%, 54 \%, 28 \%, 14.4 \%, 8.8 \%$, and $1 \%$ of the surface irradiance measured in our incubators) were sampled from the upper $100 \mathrm{~m}$ for the determination of chlorophyll a, nutrients, and nifH gene abundance and for 
$\mathrm{N}_{2}$ fixation and primary production incubations. Unfortunately, the photosynthetically active radiation detector was malfunctioned during our cruise. The sampling depths corresponding to each irradiance were decided using the average photosynthetically active radiation value measured previously in the NSCS during the same season (supporting information Figure S1).

Standard colorimetric techniques were used for the determination of $\mathrm{NO}_{3}{ }^{-}+\mathrm{NO}_{2}{ }^{-}\left(\mathrm{NO}_{\mathrm{X}}\right)$ and soluble reactive phosphorus (SRP) concentrations on board with the same detection limits of $0.03 \mu \mathrm{molL}^{-1}$ (Du et al., 2013). Trapezoidal integration method was used to calculate the $100 \mathrm{~m}$ depth-integrated nutrient concentration. The mixed layer depth (MLD) and nitracline was applied to compare the physical setting among the different stations. The MLD was defined as the depth with a $0.8{ }^{\circ} \mathrm{C}$ change from the sea surface temperature (Kara et al., 2000). The nitracline was defined as the depth at which $\mathrm{NO}_{\mathrm{X}}$ concentration equaled $0.1 \mu \mathrm{molL}^{-1}$ (Borgen et al., 2002).

\subsection{Calculation of the Degree of KI Influence}

To evaluate the influence of KI in the NSCS, an isopycnal mixing model proposed by Du et al. (2013) was applied. The basic assumption of this model is that isopycnal mixing dominates the mixing of water masses, which is detailed in both $\mathrm{Du}$ et al. (2013) and $\mathrm{Xu}$ et al. (2018). Two end-members are required for index estimation. Here we selected the SEATS station at $116^{\circ} \mathrm{E} / 18^{\circ} \mathrm{N}$ to represent the proper SCS water mass end-member and $\mathrm{P} 4$ station at $122.959^{\circ} \mathrm{E} / 20.003^{\circ} \mathrm{N}$ for the Kuroshio water mass end-member (Figure 1a). According to the assumption, we can quantify the proportion of the $\operatorname{SCS}\left(R_{\mathrm{S}}\right)$ and the Kuroshio $\left(R_{\mathrm{K}}\right)$ water for any observed water parcel in the $\theta-S$ diagram in Figure $1 \mathrm{~b}$, basing on the conservation of either potential temperature $(\theta)$ or salinity $(S)$ along an isopycnal surface (Figure $1 \mathrm{~b}$ ):

$$
\begin{gathered}
R_{\mathrm{K}}+R_{\mathrm{S}}=1, \\
R_{\mathrm{K}} \times \theta_{\mathrm{K}}+R_{\mathrm{S}} \times \theta_{\mathrm{S}}=\theta \text { or } R_{\mathrm{K}} \times S_{\mathrm{K}}+R_{\mathrm{S}} \times S_{\mathrm{S}}=S .
\end{gathered}
$$

Note that the fraction of water mass derived from this model represents a relative value of the two selected ends instead of the absolute fraction of typical Kuroshio water since the two end-members might vary in different seasons. The average of $R_{\mathrm{k}}$ values of the upper $100 \mathrm{~m}\left(R_{\text {kave-100 }}, 1 \mathrm{~m}\right.$ interval $)$ was therefore applied as a proxy, that is, the KI index to reflect the degree of KI influence at the sampling stations. The stations with $\mathrm{KI}$ index $>0.5$ were classified as KI affected, and the others were identified as the NSCS region.

\section{3. $\mathrm{N}_{2}$ Fixation and Primary Production Rate Measurements}

Duplicated $\mathrm{N}_{2}$ fixation rates were determined by the ${ }^{15} \mathrm{~N}_{2}$ gas dissolved method (Mohr et al., 2010). The ${ }^{15} \mathrm{~N}_{2}$ predissolved seawater was made with ${ }^{15} \mathrm{~N}_{2}$ gas (98.9 atom\%, Cambridge Isotope Laboratories), and a detailed procedure and the ${ }^{15} \mathrm{~N}_{2}$ gas contamination tests are described in Lu et al. (2018). After preparation, $200 \mathrm{~mL}$ of ${ }^{15} \mathrm{~N}_{2}$-enriched seawater was slowly injected into each 4.5-L polycarbonate bottle, with the enriched water constituting $<5 \%$ of the total sample volume. $\mathrm{A} \mathrm{NaH}{ }^{13} \mathrm{CO}_{3}$ (99 atom $\%{ }^{13} \mathrm{C}$, Cambridge Isotope Laboratories) solution was added (final concentration of $100 \mu \mathrm{M}$ ) to the same bottle to measure primary production rate simultaneously. After addition of tracers, the bottle was shaken intensively before incubation.

The light conditions of the incubators were manipulated by neutral density and blue (061 Mist blue; 172 Lagoon blue) filters on deck (Mourino-Carballido et al., 2011; Rijkenberg et al., 2011). After 24 hr of incubation, precombusted $\mathrm{GF} / \mathrm{F}$ filters were used to collect the particle samples $(<200 \mathrm{~mm} \mathrm{Hg}$ ). Particulate organic matter were collected from each depth at all stations to determine background ${ }^{15} \mathrm{~N}$-PON and ${ }^{13} \mathrm{C}$-POC natural abundance. All filter samples were stored at $-20{ }^{\circ} \mathrm{C}$ immediately.

An elemental analyzer coupled to a mass spectrometer (EA-IRMS, Thermo Fisher Flash HT 2000-Delta V plus) was used to determine the concentrations of particulate organic carbon (POC) and particulate organic nitrogen (PON) and their $\delta^{13} \mathrm{C}$ and $\delta^{15} \mathrm{~N}$ values. The $\mathrm{N}_{2}$ fixation and primary production rates were calculated according to Montoya et al. (1996) and Hama et al. (1983), respectively. The raw data and detailed information are shown in supporting information Data S1 and Text S1, respectively. To represent the inventories, the upper $100 \mathrm{~m}$ depth-integrated $\mathrm{N}_{2}$ fixation (INF) and primary production (IPP) were 
calculated by the trapezoidal integration method. The contributions of $\mathrm{N}_{2}$ fixation-derived nitrogen to primary production are converted using Redfield ratio of 6.6 directly.

\section{4. nifH Gene Abundance}

The seawater samples for the nifH analyses were collected from 6 (SEATS, K8, N1, A3, D6, and F1) among the 19 stations. Briefly, $4 \mathrm{~L}$ of water sample was filtered onto $0.2-\mu \mathrm{m}$ pore-sized membrane filters (Supor200, Pall Gelman, NY, USA) and then frozen in liquid $\mathrm{N}_{2}$. To extract the DNA, membranes were cut into pieces under sterile conditions and then placed in tubes containing $800 \mu \mathrm{L}$ of sucrose lysis buffer (40-mM EDTA, 50-mM Tris- $\mathrm{HCl}, 0.75-\mathrm{M}$ sucrose) for bead beating using 0.1- and 0.5-mm glass beads. The cells were broken using a physical method, agitated for 3 min in a Fast Prep machine (MP Biomedicals, USA), and frozen in liquid nitrogen three times. Lysozyme $\left(5 \mu \mathrm{L}, 100 \mathrm{mgmL}^{-1}\right)$ was then added, and the samples were incubated for $1 \mathrm{hr}$ at $37^{\circ} \mathrm{C}$. After incubation, the lysate was transferred into a new 2-mL Eppendorf tube. Proteins were digested by incubation with $1 \%$ sodium dodecyl sulfate and proteinase $\mathrm{K}$ $\left(250 \mu \mathrm{LmL}^{-1}\right)$ at $55^{\circ} \mathrm{C}$ for $2 \mathrm{hr}$ and were removed by centrifuge at $12,000 \mathrm{~g}$ for $20 \mathrm{~min}$ at $4{ }^{\circ} \mathrm{C}$ after treatment with equal volumes of phenol:chloroform:isoamyl alcohol (25:24:1) containing 5-M NaCl. As a result, the samples were separated into three layers. The top aqueous layer containing genomic DNA was transferred into a new tube, to which an equal volume of chloroform:isoamyl alcohol (24:1) was added, followed by centrifugation at $12,000 \mathrm{~g}$ for $20 \mathrm{~min}$ at $4{ }^{\circ} \mathrm{C}$. Genomic DNA was purified by precipitation with $100 \%$ isopropanol at $-20{ }^{\circ} \mathrm{C}$ overnight, followed by washing with $70 \%$ ethanol and air drying. Genomic DNA was then eluted into $50-\mu \mathrm{L}$ TE buffer and stored at $-20^{\circ} \mathrm{C}$.

The quantitative polymerase chain reaction (qPCR) analysis was targeted on the nifH phylotypes of Trichodesmium spp., unicellular cyanobacterial UCYN-A1, UCYN-A2, and UCYN-B, Richelia spp. (het-1), and a gamma-proteobacterium ( $\gamma$-24774A11) using previously designed primers and probe sets in supporting information Table S1 (Church, Jenkins, et al., 2005; Church, Short, et al., 2005; Foster et al., 2007; Langlois et al., 2008; Moisander et al., 2008; Thompson et al., 2014). The nifH standards were obtained by cloning the environmental sequences from previous samples of the SCS (Table S1). qPCR analysis was carried out as described previously (Church, Jenkins, et al., 2005) with slight modifications. Each $20-\mu \mathrm{L}$ reaction mixture contained $2 \mu \mathrm{L} 10 \times$ TaqMan $^{\circledR}$ PCR buffer (Tiangen ${ }^{\circledR}$ ), $250 \mu \mathrm{molL}^{-1}$ dNTP mixture, $250 \mathrm{nmolL}^{-1}$ of fluorogenic probe, $250 \mathrm{nmolL}^{-1}$ each of the forward and reverse primers, $0.5 \mathrm{U}$ Taq DNA polymerase $\left(\right.$ Tiangen ${ }^{\circledR}$ ) and $5 \mu \mathrm{L}$ of environmental DNA or standard. Triplicate qPCR reactions were run for each environmental DNA sample and for each standard on a CFX96 Real-Time System (Bio-Rad Laboratories). The thermal cycle program was $50{ }^{\circ} \mathrm{C}$ for $2 \mathrm{~min}$ and $94{ }^{\circ} \mathrm{C}$ for $10 \mathrm{~min}$, followed by 49 cycles of $95{ }^{\circ} \mathrm{C}$ for $15 \mathrm{~s}, 60^{\circ} \mathrm{C}$ for $1 \mathrm{~min}$. Standards corresponding to between $5 \times 10^{1}$ and $5 \times 10^{9}$ copies per well were amplified in the same 96-well plate. The copy numbers of the target genes in the environmental samples were calculated from the standard curve (supporting information Table S2). The Ct values of nontarget template were all less than the $\mathrm{Ct}$ value corresponding to $5 \times 10^{1}$ nifH copies for Trichodesmium (34.1), UCYN-A1 (36.1), UCYN-A2 (34.9), UCYN-B (34.9), het-1 (36.1), and $\gamma$-24774A11 (35.9). The detection limit of the qPCR reaction corresponded to around 50 nifH gene copies per PCR reaction, which was equivalent to around 625 gene copies per liter of seawater depending on the volume of seawater sample filtered $(4 \mathrm{~L})$. The efficiency of the PCR reaction varied between $90.3 \%$ and $95.3 \%$ (mean 93.1\%).

\subsection{Statistical Analysis}

Statistical significance was tested using a $t$ test, with values of $p<0.05$ considered significant.

\section{Results}

\subsection{Environmental Conditions}

High-temperature, high-salinity water was found in the eastern part of NSCS, which is near the Luzon Strait, specifically at given depth of isopycnal surface of the potential density anomaly ( $\sigma$ ) of 23 and $24 \mathrm{kgm}^{-3}$ (supporting information Figure S2). This distribution pattern indicates a clear intrusion of Kuroshio deep into the NSCS during the time we made our survey. In addition, the contours of the depth of the isopycnal layer (Figure S2) showed a shoaling pattern toward the west, agreeing with previous findings that the SCS is a basin-scale upwelling system (Wong et al., 2007). 
Table 1

Fundamental Parameters (Averaged Values) for the KI-Affected Region and the NSCS Region

\begin{tabular}{|c|c|c|c|}
\hline Parameter & KI-affected stations $(n=6)$ & NSCS stations $(n=13)$ & $p$ value \\
\hline Sea surface temperature $\left(\mathrm{SST},{ }^{\circ} \mathrm{C}\right)$ & $28.9 \pm 0.8$ & $29.7 \pm 0.4$ & $0.009^{* *}$ \\
\hline Sea surface salinity (SSS) & $34.53 \pm 0.05$ & $34.20 \pm 0.25$ & $<0.001^{* *}$ \\
\hline $\operatorname{MLD}(\mathrm{m})$ & $26.2 \pm 3.6$ & $19.0 \pm 4.3$ & $0.003^{* *}$ \\
\hline Nitracline depth (m) & $45.4 \pm 20.5$ & $42.5 \pm 13.3$ & 0.726 \\
\hline Surface Chla $\left(\mu \mathrm{gL}^{-1}\right)$ & $0.28 \pm 0.09$ & $0.23 \pm 0.07$ & 0.191 \\
\hline Integrated $\mathrm{NO}_{\mathrm{X}}\left(\mathrm{INO}_{\mathrm{X}}, \mathrm{mmolm}^{-2}\right)$ & $159 \pm 60$ & $256 \pm 107$ & 0.112 \\
\hline Integrated SRP (ISRP, mmolm $^{-2}$ ) & $14.6 \pm 3.4$ & $19.1 \pm 7.5$ & 0.238 \\
\hline $\mathrm{INO}_{\mathrm{X}}: \mathrm{ISRP}$ & $10.8 \pm 2.8$ & $13.2 \pm 0.8$ & $0.046^{*}$ \\
\hline Surface $\mathrm{N}_{2}$ fixation $\left(\mathrm{nmol} \mathrm{N} \cdot \mathrm{L}^{-1} \cdot\right.$ day $\left.^{-1}\right)$ & $8.5 \pm 4.1$ & $1.0 \pm 0.7$ & $0.007^{* *}$ \\
\hline Surface primary production $\left(\mu \mathrm{mol} \mathrm{C} \cdot \mathrm{L}^{-1} \cdot\right.$ day $\left.^{-1}\right)$ & $0.45 \pm 0.20$ & $0.38 \pm 0.13$ & 0.382 \\
\hline $\operatorname{INF}\left(\mu \mathrm{mol} \mathrm{N} \cdot \mathrm{m}^{-2} \cdot\right.$ day $\left.^{-1}\right)$ & $463 \pm 260$ & $50 \pm 19$ & $0.011^{*}$ \\
\hline $\operatorname{IPP}\left(\mathrm{mmol} \mathrm{C} \cdot \mathrm{m}^{-2} \cdot\right.$ day $\left.^{-1}\right)$ & $61.5 \pm 19.5$ & $27.9 \pm 10.4$ & $<0.001^{* *}$ \\
\hline INF $\mathrm{N}$ contribution to IPP (\%) & $5.1 \pm 2.5$ & $1.3 \pm 0.5$ & $0.012^{*}$ \\
\hline
\end{tabular}

Note. The Equal Variance Test was conducted using Brown-Forsythe method, with $p>0.05$ equal variance assumed. Student's $t$ test $(p>0.05)$ or Welch's $t$ test $(p<0.05)$ were conducted to compare the difference between the KI-affected stations and the NSCS stations. INF = integrated $\mathrm{N}_{2}$ fixation; IPP = integrated; primary production; KI = Kuroshio intrusion; NSCS = northern South China Sea; SST = sea surface temperature; SSS = sea surface salinity; MLD $=$ mixed layer depth; SRP = soluble reactive phosphorus.

${ }^{*} p<0.05 . \quad{ }^{* *} p<0.01$.

In the $\theta-S$ diagram (Figure $1 b$ ), almost all of our sampling stations fell within the range of the two end-members. The spatial distribution of the KI index showed a tongue-like pattern revealing the KI pathway (Figure 1a), with a much higher $R_{\text {kave-100 }}(>0.5)$ at stations close to the Luzon Strait (D4, D6, F1, F3, F7, and A3), which we defined as the KI-affected region. The remaining 13 stations with lower $R_{\text {kave-100 }}(<0.5)$ were located in the NSCS region (SEATS, K2 to K8, A6, A9, A10, N1, and E4).

The fundamental parameters are presented as the averaged values in Table 1 for the comparison of the NSCS and KI-affected regions. The mean sea surface temperature and sea surface salinity showed a significant difference between the two regions, with an average $0.8^{\circ} \mathrm{C}$ lower sea surface temperature and a slightly higher sea surface salinity (on average 0.33 ) in the KI-affected stations relative to the NSCS stations (Table 1). The MLD also revealed a significant difference between the KI-affected $(26.2 \pm 3.6 \mathrm{~m})$ and the NSCS region $(19.0 \pm 4.3 \mathrm{~m})$.

In the upper $25 \mathrm{~m}$, both concentrations of $\mathrm{NO}_{\mathrm{X}}$ and $\mathrm{SRP}$ were below the detection limit for all stations, while vertically, the concentration of nutrients increased with depth (Figure 2). The average depth of the nitracline
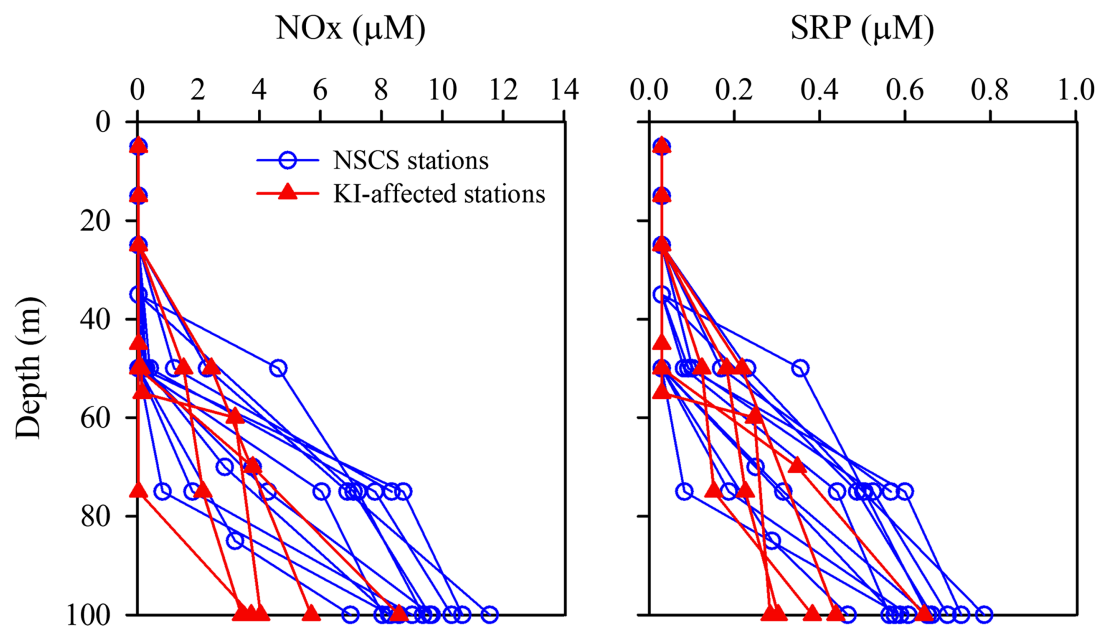

Figure 2. The vertical profiles of NOx and SRP concentration $(\mu \mathrm{M})$ at incubation stations. SRP = soluble reactive phosphorus; NSCS = northern South China Sea; KI = Kuroshio intrusion. 


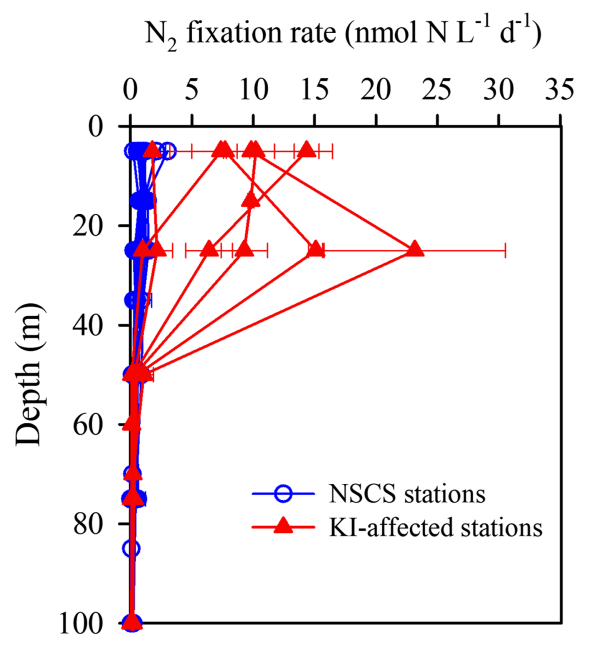

Primary production $\left(\mu \mathrm{mol} \mathrm{C} \mathrm{L} \mathrm{L}^{-1} \mathrm{~d}^{-1}\right)$

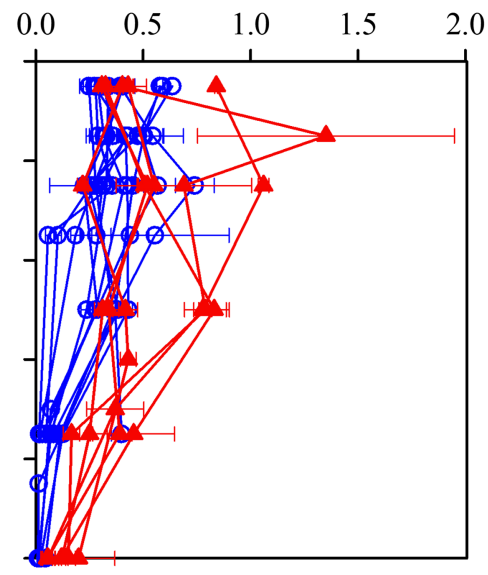

Figure 3. The vertical profiles of $\mathrm{N}_{2}$ fixation rate $\left(\mathrm{nmol} \mathrm{N} \cdot \mathrm{L}^{-1} \cdot \mathrm{day}^{-1}\right)$ and primary production $\left(\mu \mathrm{mol} \mathrm{C} \cdot \mathrm{L}^{-1} \cdot \mathrm{day}^{-1}\right)$ at incubation stations. NSCS $=$ northern South China Sea; KI $=$ Kuroshio intrusion.

in the KI-affected region $(45.4 \pm 20.5 \mathrm{~m})$ showed no difference from the NSCS region $(42.5 \pm 13.3 \mathrm{~m})$. In general, the nutrient concentrations at the depths below the $50 \mathrm{~m}$ were higher in the NSCS region than in the KI-affected (Figure 2). No significant difference of the upper $100 \mathrm{~m}$ depth-integrated NOx and SRP concentration was found between the NSCS region and the KI-affected region ( $t$ test $p>0.05$, Table 1). However, the average concentration of integrated NOx in the NSCS region $\left(256 \pm 107 \mathrm{mmolm}^{-2}\right)$ was higher than in the KI-affected region $\left(159 \pm 60 \mathrm{mmolm}^{-2}\right)$. No significant difference of depth-integrated SRP concentration was found between regions. The ratio of depth-integrated $\mathrm{NO}_{\mathrm{X}}$ to SRP in the NSCS $(13.2 \pm 0.8)$ region was significantly higher $(t$ test, $p=0.046)$ than that observed in the KI-affected region $(10.8 \pm 2.8$, Table 1$)$, showing $\mathrm{N}$ deficit of upper $100 \mathrm{~m}$ in the KI-affected region. The sea surface Chl a concentration ranged from 0.16 to $0.4 \mu \mathrm{gL}^{-1}$, showing no difference between the two regions (Table 1).

\subsection{Horizontal and Vertical Distributions of $\mathbf{N}_{2}$ Fixation and Primary Production}

The surface $(5 \mathrm{~m}) \mathrm{N}_{2}$ fixation rate ranged from 1.8 to $14.3 \mathrm{nmol} \mathrm{N} \cdot \mathrm{L}^{-1} \cdot$ day ${ }^{-1}$, with an average of $8.5 \pm 4.1 \mathrm{nmol}$ $\mathrm{N} \cdot \mathrm{L}^{-1}$. day $^{-1}$ in the KI-affected region, which was significantly higher than that observed in the NSCS region (in average $1.0 \pm 0.7 \mathrm{nmol} \mathrm{N} \cdot \mathrm{L}^{-1} \cdot$ day $^{-1}, t$ test, $p<0.001$, Figure 3 and Table 1 ). The surface primary production ranged from 0.25 to $0.84 \mu \mathrm{mol} \mathrm{C} \cdot \mathrm{L}^{-1}$. day ${ }^{-1}$ and showed no visible difference between the KI-affected and the NSCS region (Figure 3 and Table 1). Vertically, the relatively high rates of $\mathrm{N}_{2}$ fixation and primary production were found in the upper $30 \mathrm{~m}$, while below $30 \mathrm{~m}$, the rates dropped rapidly (Figure 3). The INF in the KI-affected region (ranging from 105 to $885 \mu \mathrm{mol} \mathrm{N} \cdot \mathrm{m}^{-2} \cdot$ day $^{-1}$ with an average of $463 \pm 260 \mu \mathrm{mol} \mathrm{N} \cdot \mathrm{m}^{-2}$ day $^{-1}$ ) were significantly higher than these in the NSCS region (from 29 to $89 \mu \mathrm{mol} \mathrm{N} \cdot \mathrm{m}^{-2} \cdot$ day $^{-1}$ with an average $50 \pm 19 \mu \mathrm{mol} \mathrm{N} \cdot \mathrm{m}^{-2} \cdot$ day $^{-1}, t$ test, $p<0.05$, Figure 4 a and Table 1 ). Although the surface primary production showed no noticeable difference between the KI-affected and NSCS region, the IPP were twice as high in the KI-affected region (average $61.5 \pm 19.5 \mathrm{mmol} \mathrm{C} \cdot \mathrm{m}^{-2} \cdot \mathrm{day}^{-1}$ ) than in the NSCS region (average $27.9 \pm 10.4 \mathrm{mmol} \mathrm{C} \cdot \mathrm{m}^{-2}$ day ${ }^{-1}, t$ test, $p<0.001$, Figure $4 \mathrm{~b}$ and Table 1 ).

\subsection{Contribution of $\mathrm{N}_{2}$ Fixation to $\mathbf{N}$ Demand of Primary Production}

The percent contribution of $\mathrm{N}_{2}$ fixation to the $\mathrm{N}$ demand of primary production was estimated based on a $\mathrm{C}$ : $\mathrm{N}$ ratio of 6.6. The vertical profile revealed opposite patterns between the KI-affected and NSCS regions (Figure 5). $\mathrm{N}_{2}$ fixation contributed up to $22.0 \%$ of the $\mathrm{N}$ demand of primary production in the surface water at F3, and the contributions declined to a limited level at or below $50 \mathrm{~m}$. The contributions were significantly higher in the KI-affected region (average $12.8 \%$ and $11.2 \%$ at 5 and $25 \mathrm{~m}$, respectively) than in the NSCS region (average $1.4 \%$ and $1.8 \%$ at 5 and $25 \mathrm{~m}$, respectively) at depths of 5 and $25 \mathrm{~m}$ ( $t$ test, $p<0.05$ ). At $50 \mathrm{~m}$ or below, the fractional contribution decreased to $<2 \%$ in the KI-affected region. In the NSCS region, the contribution increased with depth (up to $13.1 \%$ at $100 \mathrm{~m}$ at A10), and the average contribution at deeper depths was much higher than the contribution in the corresponding layer in the KI-affected region 

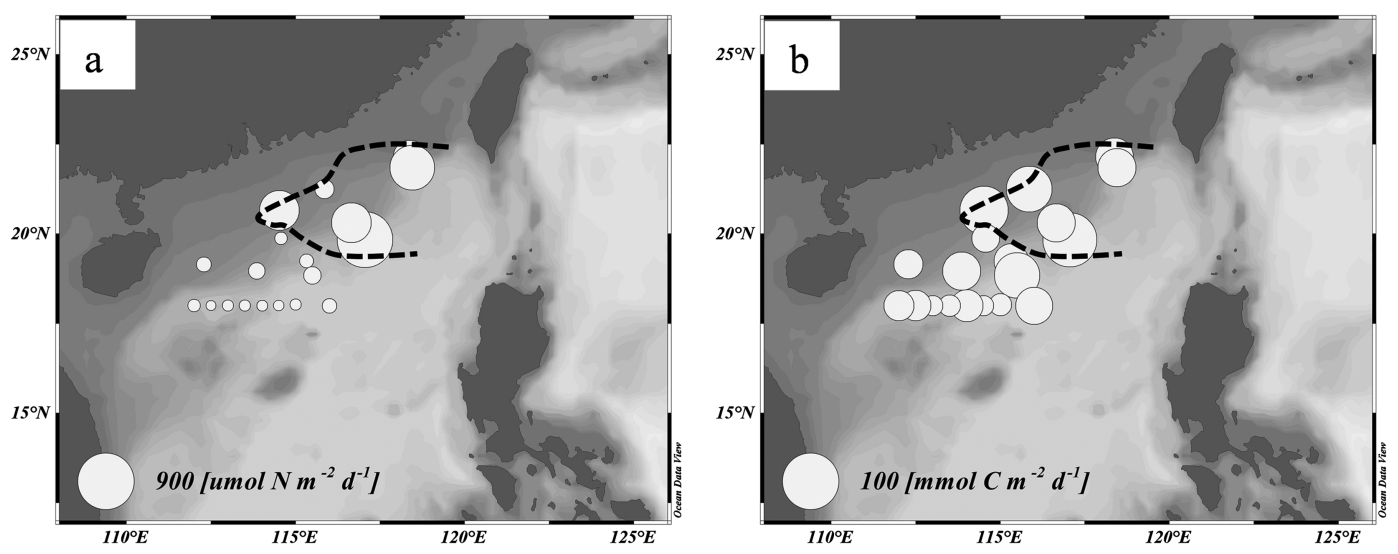

Figure 4. Spatial distributions of (a) the depth-integrated $\mathrm{N}_{2}$ fixation rate $\left(\mu \mathrm{mol} \mathrm{N} \cdot \mathrm{m}^{-2} \cdot\right.$ day $\left.^{-1}\right)$ and (b) depth-integrated primary production $\left(\mathrm{mmol} \mathrm{C} \cdot \mathrm{m}^{-2} \cdot \mathrm{day}^{-1}\right.$ ). The dashed curves represent the isopleth of Kuroshio intrusion index of 0.5.

(Figure 5). Overall, the INF accounted for $<8.2 \%$ of the $\mathrm{N}$ demand of the IPP at all stations in this study. The collective contribution of $\mathrm{N}_{2}$ fixation was significantly higher in the KI-affected region $(5.1 \pm 2.5 \%)$ than in the NSCS region $(1.3 \pm 0.5 \%, t$ test, $p=0.012$, Table 1$)$.

\subsection{Distribution of nifH Abundance}

The diazotroph groups targeted by qPCR assays were detected at six stations, except for het-1, which was undetectable in all depths (Figure 6). Trichodesmium was nearly uniformly distributed from surface to $25 \mathrm{~m}$ and generally decreased at the depth below $50 \mathrm{~m}$ (Figure 6). Instead, unicellular cyanobacterial diazotrophs were most abundant in the subsurface water $\left(25\right.$ or $50 \mathrm{~m}$ ), where UCYN-A1 reached $7.1 \times 10^{4}$ to $3.7 \times 10^{5}$ nifH gene copiesL ${ }^{-1}$. The nifH of $\gamma$-24774A11 was observed from the surface to the depth of $100 \mathrm{~m}$, and the abundance at depths showed relatively constant at around $10^{4}$ copiesL $^{-1}$ in the upper $100 \mathrm{~m}$ (Figure 6).

Trichodesmium dominated the diazotrophic phylotypes throughout the water column in the KI-affected stations (A3, D6, and F1, Figure 6). The depth-integrated abundance was 2-4 orders of magnitude greater than that of the other phylotypes (contributed $>98 \%$ of total gene abundance) and was 1-2 orders of magnitude higher than the Trichodesmium abundance in the NSCS stations (SEATS, K8, and N1, Table 2, $t$ test $p=0.048$ ).

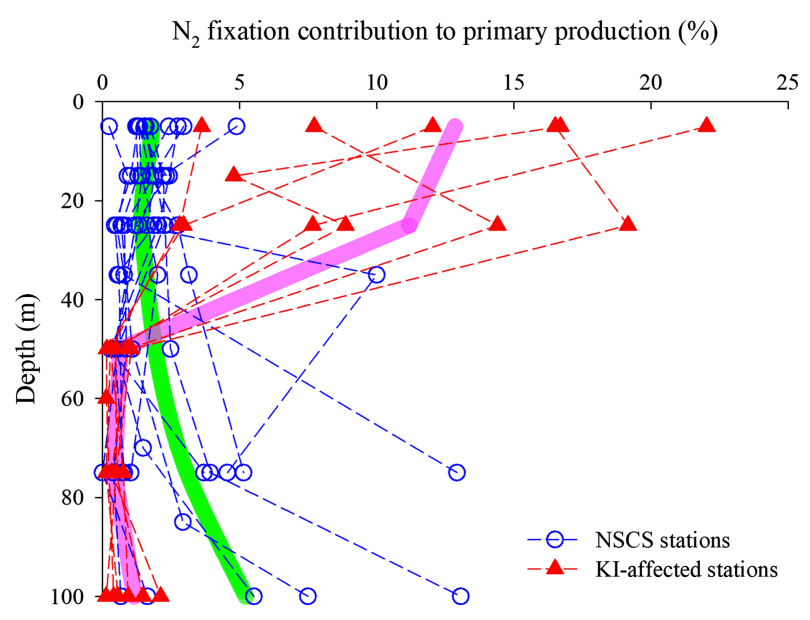

Figure 5. The depth distribution of $\mathrm{N}_{2}$ fixation contribution to the $\mathrm{N}$ demand of primary production based on Redfield ratio of 6.6. The green and pink lines represent the average contribution of $\mathrm{N}_{2}$ fixation to primary production in the NSCS region and KI-affected region, respectively. NSCS = northern South China Sea; KI = Kuroshio intrusion.
The depth-integrated abundance of unicellular cyanobacterial diazotrophs (UCYN-A1, UCYN-A2, and UCYN-B) and $\gamma$-24774A11 revealed no significant difference between the NSCS region and KI-affected region (Table $2, t$ test, $p>0.05$ ). In contrast to the KI-affected region, unicellular cyanobacterial diazotrophs contributed substantial portions at stations SEATS and K8 $(45.3 \%$ and $56.1 \%$, respectively).

\section{Discussion}

\section{1. $\mathrm{N}_{2}$ Fixation in the KI-Affected and NSCS Region}

Kuroshio water, with a higher temperature and salinity, is well known to hold relatively low inorganic nutrients but high organic nutrients in the upper water compared to the central NSCS (Du et al., 2013; Wu et al., 2015). Thus, the intrusion of Kuroshio would substantially alter the nutrient inventory and subsequently the biogeochemical cycles in the NSCS (Du et al., 2013; Wu et al., 2015; Xu et al., 2018).

In our study, the surface $\mathrm{N}_{2}$ fixation rates in the KI-affected region were significantly higher than the rates in the NSCS region (Figure 3). The average INF, $463 \pm 260 \mu \mathrm{mol} \mathrm{N} \cdot \mathrm{m}^{-2} \cdot$ day $^{-1}$, fell within the upper range of $100-1,000 \mu \mathrm{mol} \mathrm{N} \cdot \mathrm{m}^{-2} \cdot$ day $^{-1}$ in the $\mathrm{N}_{2}$ fixation 


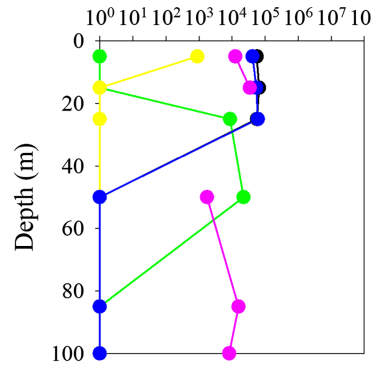

A3

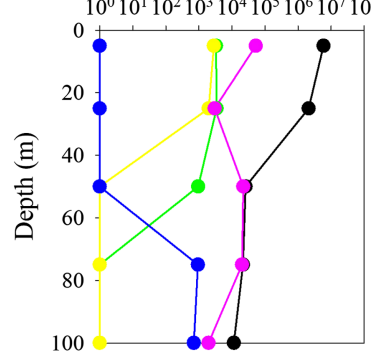

K8

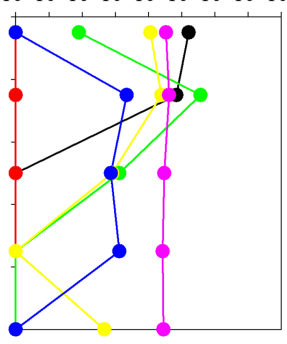

D6

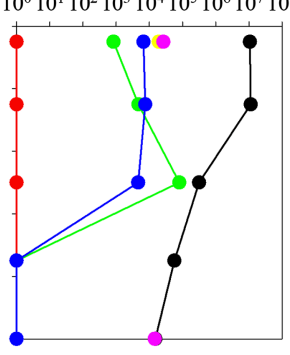

N1

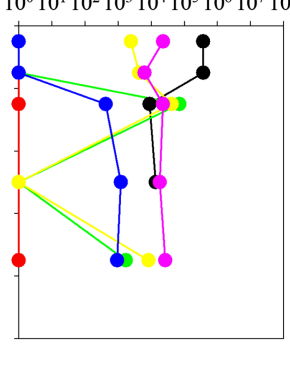

F1

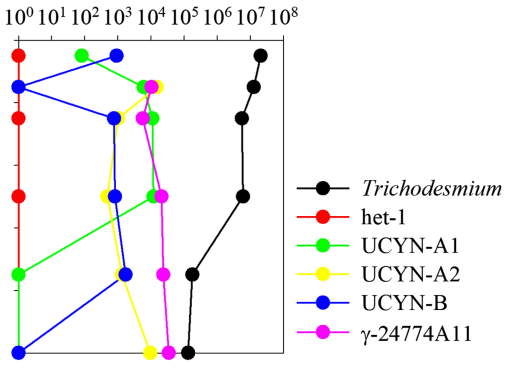

Figure 6. The vertical profiles of nifH phylotype abundances (nifH gene copiesL ${ }^{-1}$ ) at stations SEATS, K8, and N1 in the northern South China Sea (upper panels) and stations A3, D6, and F1 in the Kuroshio intrusion-affected region (lower panels).

database complied by Luo et al. (2012) and much higher than that in typical oligotrophic gyre ocean (Dore et al., 2002; Falcon et al., 2004; Knapp et al., 2016; Moore et al., 2009; Table 3). In addition, the rates resembled that in the downstream Kuroshio near Japan, ALOHA station, and the western tropical South Pacific, regions considered "hot spots" for nitrogen fixation (Berthelot et al., 2017; Bonnet et al., 2015, 2017; Böttjer et al., 2016; Shiozaki et al., 2010, 2015). The "KI-affected" region in our study was in the region Lee Chen et al. (2014) defined as "NSCS basin". To date, such high rate of nitrogen fixation in this region has not been reported previously, and the mean value was 1 order of magnitude higher than Lee Chen et al. (2014) reported (average $52 \pm 6 \mu \mathrm{mol} \mathrm{N} \cdot \mathrm{m}^{-2}$ day ${ }^{-1}$ ). The difference in $\mathrm{N}_{2}$ fixation rates between Lee Chen et al. (2014) and our study is probably due to the method inconsistency in $\mathrm{N}_{2}$ fixation measurement. In the study conducted by Lee Chen et al. (2014), ${ }^{15} \mathrm{~N}_{2}$ gas was injected directly before the incubation for $\mathrm{N}_{2}$ fixation. Recent studies have demonstrated that nitrogen fixation activity determined by the gas bubble addition method could be $>50 \%$ underestimated compared with that estimated by the ${ }^{15} \mathrm{~N}_{2}$ dissolution method (Grosskopf et al., 2012; Mohr et al., 2010). Nevertheless, even the methodology was considered, no more than $10 \%$ of the $\mathrm{N}_{2}$ fixation difference between studies can be explained. Therefore, other factors rather than methodology contributed to the high $\mathrm{N}_{2}$ fixation rates in the KI-affected region, as well as the 1 order of magnitude higher rates compared to the NSCS region, during our investigation

Table 2

Depth-Integrated (upper $100 \mathrm{~m}$ ) Gene Abundances of Five nifH Phylotypes of Dizaotroph at Six Stations We Surveyed (A3, D6, and F1 for KI-affected stations; SEATS, K8, N1 for NSCS Background Stations)

\begin{tabular}{llllll}
\hline Station & Trichodesmium & UCYN-A1 & UCYN-A2 & UCYN-B & $\gamma$-24774A11 \\
\hline SEATS & $2.21 \times 10^{9}$ & $8.28 \times 10^{8}$ & $8.93 \times 10^{6}$ & $2.02 \times 10^{9}$ & $1.24 \times 10^{9}$ \\
K8 & $4.00 \times 10^{9}$ & $8.35 \times 10^{9}$ & $7.51 \times 10^{8}$ & $1.01 \times 10^{8}$ & $3.21 \times 10^{9}$ \\
N1 & $3.20 \times 10^{10}$ & $1.27 \times 10^{9}$ & $9.03 \times 10^{8}$ & $4.96 \times 10^{7}$ & $1.48 \times 10^{9}$ \\
A3 & $1.37 \times 10^{11}$ & $1.50 \times 10^{8}$ & $8.69 \times 10^{7}$ & $3.22 \times 10^{7}$ & $1.93 \times 10^{9}$ \\
D6 & $4.24 \times 10^{11}$ & $2.12 \times 10^{9}$ & $2.88 \times 10^{8}$ & $3.22 \times 10^{7}$ & $5.79 \times 10^{8}$ \\
F1 & $5.84 \times 10^{11}$ & $5.51 \times 10^{8}$ & $3.31 \times 10^{8}$ & $8.58 \times 10^{7}$ & $1.74 \times 10^{9}$ \\
\hline
\end{tabular}

Note. The het-1 nifH gene abundances were undetectable at all stations. KI = Kuroshio intrusion; NSCS = northern South China Sea. 
Table 3

\begin{tabular}{llcc} 
The Reported N Fluxes in Global Ocean & and Measured INF in This Study $\left(\mu m o l ~ N \cdot m^{-2} \cdot\right.$ day & \\
Region & Research type & Flux or INF & Reference \\
\hline NSCS basin & $\mathrm{N}_{2}$ fixation & $45.3 \pm 6.2$ & Lee Chen et al. (2014) \\
Kuroshio upstream & $\mathrm{N}_{2}$ fixation & $180.5 \pm 34.3$ & Lee Chen et al. (2014) \\
Kuroshio downstream & $\mathrm{N}_{2}$ fixation & $199 \pm 142$ & Shiozaki et al. (2015) \\
NSCS basin & $\mathrm{N}_{2}$ fixation & $50 \pm 19$ & this study \\
KI-affected NSCS & $\mathrm{N}_{2}$ fixation & $463 \pm 260$ & this study \\
ALOHA & $\mathrm{N}_{2}$ fixation & $230 \pm 136$ & Böttjer et al. (2016) \\
North Pacific Ocean & $\mathrm{N}_{2}$ fixation & $30-120$ & Dore et al. (2002) \\
South Pacific Ocean & $\mathrm{N}_{2}$ fixation & $23-98$ & Knapp et al. (2016) \\
Tropical North Atlantic Ocean & $\mathrm{N}_{2}$ fixation & $73-90$ & Falcon et al. (2004) \\
South Atlantic Ocean & $\mathrm{N}_{2}$ fixation & $\sim 20$ & Moore et al. (2009) \\
NSCS basin & Atmospheric deposition & $20-150$ & Kao et al. (2012), \\
& & & Kim et al. (2014), \\
& & & Yang et al. (2014) \\
NSCS basin & Export PON flux & $365-650$ & Cai et al. (2015), \\
Kuroshio upstream & & & Chen et al. (1998) \\
\hline
\end{tabular}

Note. $\mathrm{INF}=$ depth-integrated $\mathrm{N}_{2}$ fixation; $\mathrm{KI}=$ Kuroshio intrusion; NSCS = northern South China Sea; $\mathrm{PON}=$ particulate organic nitrogen.

(Figures 3 and 4). Lee Chen et al. (2014) found that the INF in the main stream Kuroshio was several times higher than that in the NSCS basin. They suggested that the much deeper nitracline in the upstream Kuroshio might provide a suitable condition for diazotrophs competing for nutrients (such as Fe and P) with fast-growth nondiazotrophs (Lee Chen et al., 2003, 2008, 2014). In addition, bio-essential Fe sourced from the islands upstream (Aguilar-Islas et al., 2007; Blain et al., 2007) and the continental shelf due to sediment resuspension and pore water diffusion (Bruland et al., 2005; Lam \& Bishop, 2008), probably promote diazotrophic abundance and activity along the Kuroshio Current (Shiozaki et al., 2015). Thus, the high rates of $\mathrm{N}_{2}$ fixation appeared in the KI-affected region probably due to the lateral transport from the main stream of the Kuroshio.

\subsection{Advection of Trichodesmium to the NSCS}

In the NSCS region, other diazotrophic phylotypes rather than Trichodesmium dominated the nifH gene abundance at stations SEATS and K8. The unicellular cyanobacterial diazotrophs (UCYN-A1, UCYN-A2, and UCYN-B) account for around half of the total gene abundance, while the Trichodesmium and $\gamma$-24774A11 composed less than $30 \%$, respectively (Table 2 ). The result was consistent to previous findings that unicellular cyanobacterial diazotrophs were the major contributors to the $\mathrm{N}_{2}$ fixation in the NSCS
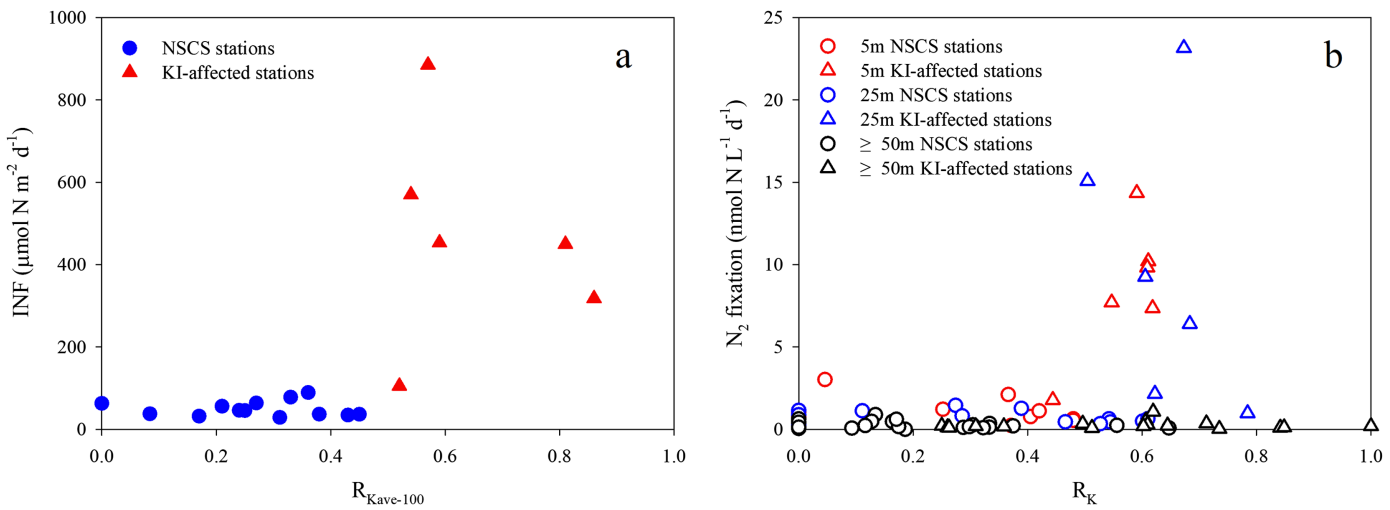

Figure 7. (a) The depth-integrated (upper $100 \mathrm{~m}$ ) $\mathrm{N}_{2}$ fixation rate (INF, $\mu \mathrm{mol} \mathrm{N} \cdot \mathrm{m}^{-2} \cdot$ day $^{-1}$ ) against the average Kuroshio fraction in the upper $100 \mathrm{~m}$; (b) $\mathrm{N}_{2}$ fixation rate $\left(\mathrm{nmol} \mathrm{N} \cdot \mathrm{L}^{-1}\right.$.day $\left.{ }^{-1}\right)$ against the Kuroshio fraction at each depth $(5,25$, and $50 \mathrm{~m})$. NSCS $=$ northern South China Sea; KI = Kuroshio intrusion. 


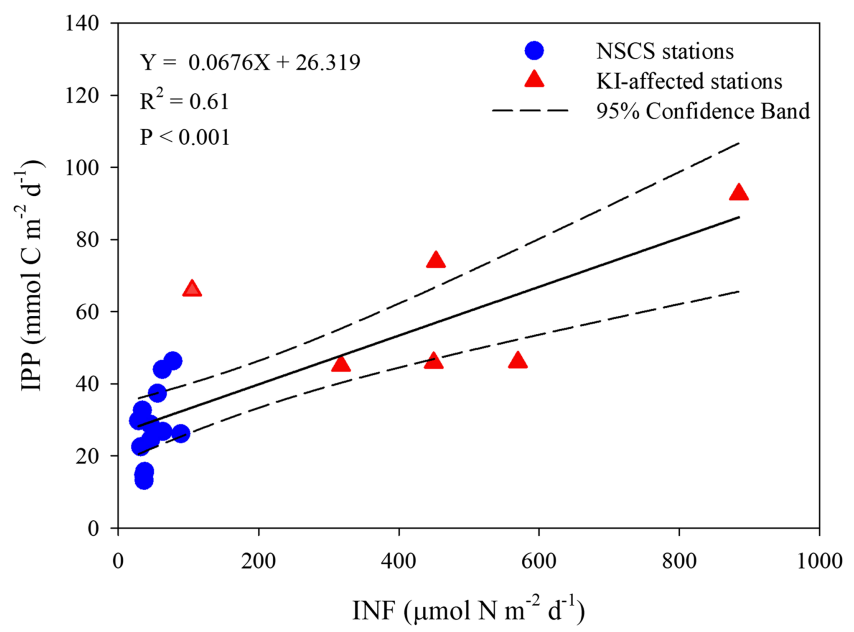

Figure 8. Linear correlation between INF and IPP for all 19 stations. Solid triangles represent the KI-affected stations, while the solid circles represent the NSCS stations. NSCS = northern South China Sea; KI = Kuroshio intrusion; $\mathrm{INF}=$ integrated $\mathrm{N}_{2}$ fixation; IPP = integrated primary production.
(Lee Chen et al., 2014; Wong et al., 2015). In addition to unicellular cyanobacterial diazotrophs, proteobacteria was also found to be a potential $\mathrm{N}_{2}$ fixation contributor in the SCS (Kong et al., 2011; Zhang et al., 2011). The absolute depth-integrated abundances of UCYN-A1, UCYN-A2, UCYN-B, and $\gamma$-24774A11 revealed no significant difference between the NSCS region and KI-affected region (Table 2). In contrast, Shiozaki, Lee Chen, et al. (2014) found orders of magnitude higher of UCYN-B abundance in the main stream of Kuroshio in summer than that in NSCS. During our cruise, we did not investigate the stations in the main stream Kuroshio. Thus, we are not sure whether there is a high abundance of UCYN-B in the Kuroshio as found by Shiozaki, Lee Chen, et al. (2014). Nevertheless, the intrusion of Kuroshio likely creates a new biogeographic regime in the front zone suitable for the growth of Trichodesmium.

The orders of magnitude higher Trichodesmium abundance in the KIaffected region relative to the NSCS background strongly suggests the observed high $\mathrm{N}_{2}$ fixation rates was attributed to Trichodesmium brought by the Kuroshio. In the oligotrophic ocean, Trichodesmium often formed extensive bloom in stratified water with low turbulence, slow $\mathrm{NO}_{3}{ }^{-}$input from deep water, and a sufficient supply of Fe and P (Capone et al., 1997). Thus, the environmental conditions in the Kuroshio might suitable for Trichodesmium. Indeed, Trichodesmium dominated the diazotrophic community in the main stream of Kuroshio, especially around islands (Lee Chen et al., 2003; Shiozaki et al., 2015). Given its buoyant feature, the distribution pattern of Trichodesmium can be regulated by the ocean currents. For example, Trichodesmium in the western subtropical North Atlantic can be transported by the Gulf Steam to the high-latitude regions (Lipschultz \& Owens, 1996). Similarly, Trichodesmium flourished around islands in upper stream of the Kuroshio can be transported to the downstream region near Japan (Shiozaki et al., 2015). Thus, we infer that the high abundance of Trichodesmium in KI-affected region during our study may be transported from the main stream of Kuroshio during the intrusion events, which significantly enhance the $\mathrm{N}_{2}$ fixation rate in the regions with $R_{\mathrm{k}}>0.5$ (Figures 4 and 7). However, we found higher INF values with higher KI index, yet the highest INF did not appear at the Kuroshio end (Figure 7a). Since the majority of the $\mathrm{N}_{2}$ fixation had occurred in the surface $30 \mathrm{~m}$, we combined the measurements of the corresponding layers for comparison (Figure $7 \mathrm{~b}$ ) and found that the high $\mathrm{N}_{2}$ fixation values located at $\mathrm{KI}$ index are around 0.6 in the surface 5 and $25 \mathrm{~m}$. Either we missed sampling the surface waters from regions with high KI index during our cruise or some other process further amplified the nitrogen fixation in the shallow water at stations with $R_{\mathrm{k}}$ of around 0.5-0.6. Our results demonstrated that diazotrophs (mainly Trichodesmium) and high $\mathrm{N}_{2}$ fixation were tightly associated with the KI, which modulated the biogeographic distribution of $\mathrm{N}_{2}$ fixers.

To better estimate the global $\mathrm{N}_{2}$ fixation budget and understand the role of $\mathrm{N}_{2}$ fixation in the biogeochemical cycles of complicated physical domains, further studies are required to explore the influence of this kind of boundary current effect and its spreading capacity and the biogeochemical behavior therein. Further isotope and molecular level studies are needed to constrain the internal mechanisms to stimulate on-site $\mathrm{N}_{2}$ fixation or to sustain diazotrophs over long-distance travel.

\subsection{Linkage Between Nitrogen Fixation, New Production and Primary Production}

Linking to the biological pump, the amount of $\mathrm{N}_{2}$ fixation was comparable with previously reported export production, accounting for 50-100\% of the export production in the NSCS euphotic zone (Cai et al., 2015; Chen et al., 1998, 2008; Table 3). Such a high contribution suggests that $\mathrm{N}_{2}$ fixation associated with the KI alone may play a considerable role in the biogeochemical cycles of carbon and nitrogen in the SCS.

Relative to the diapycnal supply of dissolved inorganic nitrogen $\left(\sim 110 \mu \mathrm{mol} \mathrm{N} \cdot \mathrm{m}^{-2} \cdot \mathrm{day}^{-1}\right)$ to the euphotic zone observed previously at SEATS (Du et al., 2017), the water column INF rates were much lower in the NSCS region $\left(\sim 50 \mu \mathrm{mol} \mathrm{N} \cdot \mathrm{m}^{-2} \cdot\right.$ day $\left.^{-1}\right)$. In contrast, the INF was $\sim 4$ times higher in the KI-affected region, 
as high as $460 \mu \mathrm{mol} \mathrm{N} \cdot \mathrm{m}^{-2}$. day ${ }^{-1}$. Such high INF rates demonstrate the significance of the lateral input of new nitrogen induced by diazotrophs. It also suggests that the primary producers in the KI-affected region benefitted from the nitrogen input via diazotrophs during our sampling period.

A significant positive correlation was obtained between the INF and the IPP across the 19 research stations (Figure $8, R^{2}=0.61, p<0.001$ ). The high INF is accompanied with relatively high IPP in the KI-affected region, implying the potential role of diazotrophs in the primary productivity. Our result was in line with the findings of previous mesocosm studies, in which higher primary production was associated with higher $\mathrm{N}_{2}$ fixation (Berthelot et al., 2015; Van Wambeke et al., 2016). Similarly, in field studies, $\mathrm{N}_{2}$ fixation were reported to have a positive linear relationship with primary production regardless surface or water column integrated (Bonnet et al., 2015; Shiozaki et al., 2018).

As indicated in Figure 5, the $\mathrm{N}_{2}$ fixers were not the mainly contributor of primary production. Assuming that most $\mathrm{N}_{2}$ fixation activity was contributed by cyanobacterial diazotrophs, collectively, the measured INF in the upper $100 \mathrm{~m}$ may only account for $\sim 1.3 \%$ of the N demand of IPP in the NSCS region and $\sim 5.1 \%$ in the $\mathrm{KI}$-affected region, despite the maximum contribution reaching as high as $\sim 22 \%$ in the surface water (Figure 5). It is likely that additional nitrogen sources associated with Trichodesmium activity generated a linear correlation between INF and IPP.

Principally, Trichodesmium has been shown to release a substantial portion (up to 90\%) of newly fixed nitrogen to the dissolved pool and transfer it to nondiazotrophs in the short term ( $24 \mathrm{hr}$; Bonnet et al., 2016; Lee Chen et al., 2011; Mulholland \& Bernhardt, 2005). This new bioavailable nitrogen derived from Trichodesmium may accumulate and substantially enhance regenerated production in the euphotic zone (Shiozaki et al., 2018). In many previous studies, bacterial production was limited by lack of bioavailable $\mathrm{N}$. Thus, the accumulated newly fixed nitrogen, on the other hand, may stimulate bacterial production, which could degrade more dissolved organic matter into bioavailable $\mathrm{N}$ and relax the $\mathrm{N}$ limitation for primary producers in the euphotic zone (Berthelot et al., 2015; Van Wambeke et al., 2016). At depths below $25 \mathrm{~m}$, the contribution of $\mathrm{N}_{2}$ fixation to primary production declined quickly to a level of $<2 \%$ at the depth of $50 \mathrm{~m}$ in the KI-affected region (Figure 5). Although most $\mathrm{N}_{2}$ fixation and primary production both are light driven in euphotic zone, under low-light stress, Trichodesmium physiologically preferred to allocate more energy for carbon fixation to alleviate the intensive carbon consumption by respiration, thus nearly shutting down $\mathrm{N}_{2}$ fixation at depths below $50 \mathrm{~m}$ (Lu et al., 2018). On the other hand, low-light stress may further enhance the diazotrophic-derived nitrogen release by Trichodesmium to the surrounding water directly or indirectly (Bonnet et al., 2016; Lu et al., 2018; Mulholland et al., 2004). Although not settled, three mechanisms (diazotrophic-derived nitrogen release, new nitrogen accumulation, and stimulation of heterotrophic bacterial productivity) are offered here to explain the linear relationship between INF and IPP and to address the role of Trichodesmium in the coupled nitrogen and carbon cycle from a biogeochemical perspective.

In the NSCS region, the opposite vertical pattern of $\mathrm{N}_{2}$ fixation contribution to the $\mathrm{N}$ demand of primary production was probably induced by the distinct diazotrophic abundance and community structure (Figures 5 and 6). Apparently, the total primary production in the NSCS region was mainly maintained by the $\mathrm{N}$ flux from the deep water (Lee Chen et al., 2008), thus, diazotrophs may play a minor role in carbon fixation. Unicellular cyanobacterial diazotrophs and proteobacterium were the dominant diazotrophic species at station SEATS and K8, which most likely support the observed $\mathrm{N}_{2}$ fixation (Table 2). The fate of dinitrogen fixed by unicellular cyanobacterial diazotrophs and proteobacterium is not well understood. Among which, the unicellular cyanobacterial UCYN-A lacks key genes for carbon fixation and thus lives in symbioses with specific eukaryotic algae (Bombar et al., 2014; Tripp et al., 2010). It is known that dinitrogen fixed by UCYN-A efficiently transferred to its host (Martinez-Perez et al., 2016), and thus the surrounding planktonic communities may not benefit from this new nitrogen directly in short term (Shiozaki et al., 2018).

\section{Conclusions}

The seasonal intrusion of the western boundary Kuroshio Current into the SCS may not only influence the nutrient structure but also the community of diazotrophs, the $\mathrm{N}_{2}$ fixation rate, and primary productivity as well. Our findings provide clues to linking the physical circulation pattern to biogeochemistry and 
demonstrate that the western boundary current could effectively spreads the active Trichodesmium-dominated $\mathrm{N}_{2}$-fixation signal widely. Meanwhile, a significant positive correlation between $\mathrm{N}_{2}$ fixation and primary productivity shows that $\mathrm{N}_{2}$ fixation is tightly tied to marine carbon cycling, although the mechanisms remain unresolved.

\section{References}

Aguilar-Islas, A. M., Hurst, M. P., Buck, K. N., Sohst, B., Smith, G. J., Lohan, M. C., \& Bruland, K. W. (2007). Micro- and macronutrients in the southeastern Bering Sea: Insight into iron-replete and iron-depleted regimes. Progress in Oceanography, 73(2), 99-126. https://doi. org/10.1016/j.pocean.2006.12.002

Bergman, B., Sandh, G., Lin, S., Larsson, J., \& Carpenter, E. J. (2013). Trichodesmium - A widespread marine cyanobacterium with unusual nitrogen fixation properties. FEMS Microbiology Reviews, 37(3), 286-302. https://doi.org/10.1111/j.1574-6976.2012.00352.x

Berthelot, H., Benavides, M., Moisander, P. H., Grosso, O., \& Bonnet, S. (2017). High-nitrogen fixation rates in the particulate and dissolved pools in the western tropical Pacific (Solomon and Bismarck Seas). Geophysical Research Letters, 44, 8414-8423. https://doi.org/10.1002/ $2017 \mathrm{gl073856}$

Berthelot, H., Moutin, T., L'Helguen, S., Leblanc, K., Hélias, S., Grosso, O., et al. (2015). Dinitrogen fixation and dissolved organic nitrogen fueled primary production and particulate export during the VAHINE mesocosm experiment (New Caledonia lagoon). Biogeosciences, 12(13), 4099-4112. https://doi.org/10.5194/bg-12-4099-2015

Blain, S., Quéguiner, B., Armand, L., Belviso, S., Bombled, B., Bopp, L., et al. (2007). Effect of natural iron fertilization on carbon sequestration in the Southern Ocean. Nature, 446(7139), 1070-1074. https://doi.org/10.1038/nature05700

\section{Acknowledgments}

We are grateful to National Natural Science Foundation of China (NSFC U1305233, 41376116, 41721005, and 91328207), National Key Basic Research Program of China (973 Program 2014CB953702 and 2015CB954003), and Scientific Research Fund of the Second Institute of Oceanography, SOA (SZ1914). Thanks for help from technicians Tian Li and Zou Wenbin in determination of POC and PON and their $\delta^{13} \mathrm{C}$ and $\delta^{15} \mathrm{~N}$ values, who are in our Nitrogen Cycle Group at the State Key Laboratory of Marine Environmental Science (Xiamen University, China). Data sets for this paper are available in the supporting information.
Bombar, D., Heller, P., Sanchez-Baracaldo, P., Carter, B. J., \& Zehr, J. P. (2014). Comparative genomics reveals surprising divergence of two closely related strains of uncultivated UCYN-A cyanobacteria. The ISME Journal, 8(12), 2530-2542. https://doi.org/10.1038/ ismej.2014.167

Bonnet, S., Berthelot, H., Turk-Kubo, K., Cornet-Barthaux, V., Fawcett, S., Berman-Frank, I., et al. (2016). Diazotroph derived nitrogen supports diatom growth in the South West Pacific: A quantitative study using nanoSIMS. Limnology and Oceanography, 61(5), 1549-1562. https://doi.org/10.1002/lno.10300

Bonnet, S., Caffin, M., Berthelot, H., \& Moutin, T. (2017). Hot spot of $\mathrm{N}_{2}$ fixation in the western tropical South Pacific pleads for a spatial decoupling between $\mathrm{N}_{2}$ fixation and denitrification. PNAS, 114, E2800-E2801. https://doi.org/10.1073/pnas.1619514114

Bonnet, S., Rodier, M., Turk-Kubo, K. A., Germineaud, C., Menkes, C., Ganachaud, A., et al. (2015). Contrasted geographical distribution of $\mathrm{N}_{2}$ fixation rates and nifH phylotypes in the Coral and Solomon Seas (southwestern Pacific) during austral winter conditions. Global Biogeochemical Cycles, 29, 1874-1892. https://doi.org/10.1002/2015gb005117

Borgen, R. L., Barber, R. T., Delcroix, T., Inoue, H. Y., Mackey, D. J., \& Rodier, M. (2002). Pacific warm pool and divergence: Temporal and zonal variations on the equator and their effects on the biological pump. Deep Sea Research, 49(13-14), 2471-2512. https://doi.org/ 10.1016/S0967-0645(02)00045-0

Böttjer, D., Dore, J. E., Karl, D. M., Letelier, R. M., Mahaffey, C., Wilson, S. T., et al. (2016). Temporal variability of nitrogen fixation and particulate nitrogen export at Station ALOHA. Limnology and Oceanography. https://doi.org/10.1002/lno.10386

Bruland, K. W., Rue, E. L., Smith, G. J., \& DiTullio, G. R. (2005). Iron, macronutrients and diatom blooms in the Peru upwelling regime: Brown and blue waters of Peru. Marine Chemistry, 93(2-4), 81-103. https://doi.org/10.1016/j.marchem.2004.06.011

Cai, P., Zhao, D., Wang, L., Huang, B., \& Dai, M. (2015). Role of particle stock and phytoplankton community structure in regulating particulate organic carbon export in a large marginal sea. Journal of Geophysical Research: Oceans, 120, 2063-2095. https://doi.org/ $10.1002 / 2014 \mathrm{JC} 010432$

Capone, D. G., Burns, J. A., Montoya, J. P., Subramaniam, A., Mahaffey, C., Gunderson, T., et al. (2005). Nitrogen fixation by Trichodesmium spp.: An important source of new nitrogen to the tropical and subtropical North Atlantic Ocean. Global Biogeochemical Cycles, 19, GB2024. https://doi.org/10.1029/2004GB002331

Capone, D. G., Zehr, J. P., Paerl, H. W., Badger, M. R., \& Carpenter, E. J. (1997). Trichodesmium, a globally significant marine cyanobacterium. Science, 276, 1221-1229. https://doi.org/10.1126/science.276.5316.1221.

Chen, J., Zheng, L., Wiesner, M., Chen, R., Zheng, Y., \& Wong, H. (1998). Estimations of primary production and export production in the South China Sea based on sediment trap experiments. Chinese Science Bulletin, 43(7), 583-586. https://doi.org/10.1007/Bf02883645

Chen, W., Cai, P., Dai, M., \& Wei, J. (2008). (234)Th/(238)U disequilibrium and particulate organic carbon export in the northern South China Sea. Journal of Oceanography, 64(3), 417-428. https://doi.org/10.1007/s10872-008-0035-z

Church, M. J., Jenkins, B. D., Karl, D. M., \& Zehr, J. P. (2005). Vertical distributions of nitrogen fixing phylotypes at Stn ALOHA in the oligotrophic North Pacific Ocean. Aquatic Microbial Ecology, 38, 3-14. https://doi.org/10.3354/ame038003

Church, M. J., Short, C. M., Jenkins, B. D., Karl, D. M., \& Zehr, J. P. (2005). Temporal patterns of nitrogenase gene (nifH) expression in the oligotrophic North Pacific Ocean. Applied and Environmental Microbiology, 71(9), 5362-5370. https://doi.org/10.1128/ AEM.71.9.5362-5370

Davis, C. S., \& McGillicuddy, D. J. (2006). Transatlantic abundance of the $\mathrm{N}_{2}$-fixing colonial cyanobacterium Trichodesmium. Science, 312(5779), 1517-1520. https://doi.org/10.1126/science.1123570.

Dore, J. E., Brum, J. R., Tupas, L. M., \& Karl, D. M. (2002). Seasonal and interannual variability in sources of nitrogen supporting export in the oligotrophic subtropical North Pacific Ocean. Limnology and Oceanography, 47(6), 1595-1607. https://doi.org/10.4319/ lo.2002.47.6.1595

Du, C., Liu, Z., Dai, M., Kao, S. J., Cao, Z., Zhang, Y., et al. (2013). Impact of the Kuroshio intrusion on the nutrient inventory in the upper northern South China Sea: Insights from an isopycnal mixing model. Biogeosciences, 10, 1-14. https://doi.org/10.5194/bg-10-1-2013.

Du, C., Liu, Z., Kao, S. J., \& Dai, M. (2017). Diapycnal fluxes of nutrients in an oligotrophic oceanic regime: The South China Sea. Geophysical Research Letters, 44, 11,510-11,518. https://doi.org/10.1002/2017GL074921

Dupouy, C., Benielli-Gary, D., Neveux, J., Dandonneau, Y., \& Westberry, T. K. (2011). An algorithm for detecting Trichodesmium surface blooms in the south western tropical Pacific. Biogeosciences, 8(12), 3631-3647. https://doi.org/10.5194/bg-8-3631-2011

Falcon, L. I., Carpenter, E. J., Cipriano, F., Bergman, B., \& Capone, D. G. (2004). $\mathrm{N}_{2}$ fixation by unicellular bacterioplankton from the Atlantic and Pacific Oceans: Phylogeny and in situ rates. Applied and Environmental Microbiology, 70(2), 765-770. https://doi.org/ 10.1128/aem.70.2.765-770 
Fong, A. A., Karl, D. M., Lukas, R., Letelier, R. M., Zehr, J. P., \& Church, M. J. (2008). Nitrogen fixation in an anticyclonic eddy in the oligotrophic North Pacific Ocean. The ISME Journal, 2(6), 663-676. https://doi.org/10.1038/ismej.2008.22

Foster, R. A., Subramaniam, A., Mahaffey, C., Carpenter, E. J., Capone, D. G., \& Zehr, J. P. (2007). Influence of the Amazon River plume on distributions of free-living and symbiotic cyanobacteria in the western tropical North Atlantic Ocean. Limnology and Oceanography, 52(2), 517-532. https://doi.org/10.4319/lo.2007.52.2.0517

Grosskopf, T., Mohr, W., Baustian, T., Schunck, H., Gill, D., Kuypers, M. M. M., et al. (2012). Doubling of marine dinitrogen-fixation rates based on direct measurements. Nature, 488(7411), 361-364. https://doi.org/10.1038/nature11338

Hama, T., Miyazaki, T., Ogawa, Y., Iwakuma, T., Takahashi, M., Otsuki, A., \& Ichimura, S. (1983). Measurement of photosynthetic production of a marine phytoplankton population using a stable ${ }^{13} \mathrm{C}$ isotope. Marine Biology, $73(1), 31-36$. https://doi.org/10.1007/ BF00396282

Hung, C. C., \& Gong, G. C. (2007). Export flux of POC in the main stream of the Kuroshio. Geophysical Research Letters, 34, L18606. https://doi.org/10.1029/2007Gl030236

Kao, S. J., Yang, J. Y. T., Liu, K. K., Dai, M., Chou, W. C., Lin, H. L., \& Ren, H. (2012). Isotope constraints on particulate nitrogen source and dynamics in the upper water column of the oligotrophic South China Sea. Global Biogeochemical Cycles, 26, GB2033. https://doi.org/ 10.1029/2011GB004091

Kara, A. B., Rochford, P. A., \& Hurlburt, H. E. (2000). An optimal definition for ocean mixed layer depth. Journal of Geophysical Research, 105(C7), 16803-16821. https://doi.org/10.1029/2000JC900072

Kim, T. W., Lee, K., Duce, R., \& Liss, P. (2014). Impact of atmospheric nitrogen deposition on phytoplankton productivity in the South China Sea. Geophysical Research Letters, 41, 3156-3162. https://doi.org/10.1002/2014GL059665

Knapp, A. N., Casciotti, K. L., Berelson, W. M., Prokopenko, M. G., \& Capone, D. G. (2016). Low rates of nitrogen fixation in eastern tropical South Pacific surface waters. PNAS, 113(16), 4398-4403. https://doi.org/10.1073/pnas.1515641113

Kong, L., Jing, H., Kataoka, T., Sun, J., \& Liu, H. (2011). Phylogenetic diversity and spatio-temporal distribution of nitrogenase genes (nifH) in the northern South China Sea. Aquatic Microbial Ecology, 65(1), 15-27. https://doi.org/10.3354/ame01531

Lam, P. J., \& Bishop, J. K. B. (2008). The continental margin is a key source of iron to the HNLC North Pacific Ocean. Geophysical Research Letters, 35, L07608. https://doi.org/10.1029/2008GL033294

Langlois, R. J., Hummer, D., \& LaRoche, J. (2008). Abundances and distributions of the dominant nifH phylotypes in the Northern Atlantic Ocean. Applied and Environmental Microbiology, 74(6), 1922-1931. https://doi.org/10.1128/AEM.01720-07

Lee Chen, Y. L., Chen, H. Y., \& Lin, Y. H. (2003). Distribution and downward flux of Trichodesmium in the South China Sea as influenced by the transport from the Kuroshio Current. Marine Ecology Progress Series, 259, 47-57. https://doi.org/10.3354/meps259047.

Lee Chen, Y. L., Chen, H. Y., Lin, Y. H., Yong, T. C., Taniuchi, Y., \& Tuo, S. H. (2014). The relative contributions of unicellular and filamentous diazotrophs to $\mathrm{N}_{2}$ fixation in the South China Sea and the upstream Kuroshio. Deep Sea Research, 85, 56-71. https://doi.org/ 10.1016/j.dsr.2013.11.006

Lee Chen, Y. L., Chen, H. Y., Tuo, S. H., \& Ohki, K. (2008). Seasonal dynamics of new production from Trichodesmium $\mathrm{N}_{2}$ fixation and nitrate uptake in the upstream Kuroshio and South China Sea basin. Limnology and Oceanography, 53, 1705-1721. https://doi.org/ 10.4319/lo.2008.53.5.1705

Lee Chen, Y. L., Tuo, S. H., \& Chen, H. Y. (2011). Co-occurrence and transfer of fixed nitrogen from Trichodesmium spp. to diatoms in the low-latitude Kuroshio Current in the NW Pacific. Marine Ecology Progress Series, 421, 25-38. https://doi.org/10.3354/meps08908

Lipschultz, F., \& Owens, N. J. P. (1996). An assessment of nitrogen fixation as a source of nitrogen to the North Atlantic Ocean. Biogeochemistry, 35(1), 261-274. https://doi.org/10.1007/Bf02179830

Lu, Y., Wen, Z., Shi, D., Chen, M., Zhang, Y., Bonnet, S., et al. (2018). Effect of light on $\mathrm{N}_{2}$ fixation and net nitrogen release of Trichodesmium in a field study. Biogeosciences, 15(1), 1-12. https://doi.org/10.5194/bg-15-1-2018.

Luo, Y. W., Doney, S. C., Anderson, L. A., Benavides, M., Berman-Frank, I., Bode, A., et al. (2012). Database of diazotrophs in global ocean abundance, biomass and nitrogen fixation rates. Earth System Science Data, 4(1), 47-73. https://doi.org/10.5194/essd-4-47-2012

Martinez-Perez, C., Mohr, W., Löscher, C. R., Dekaezemacker, J., Littmann, S., Yilmaz, P., et al. (2016). The small unicellular diazotrophic symbiont, UCYN-A, is a key player in the marine nitrogen cycle. Nature Microbiology, 1, 16163. https://doi.org/10.1038/ NMICROBIOL.2016.163

Mohr, W., Großkopf, T., Wallace, D. W., \& LaRoche, J. (2010). Methodological underestimation of oceanic nitrogen fixation rates. PLoS ONE, 5(9), e12583. https://doi.org/10.1371/journal.pone.0012583.g001.

Moisander, P. H., Beinart, R. A., Voss, M., \& Zehr, J. P. (2008). Diversity and abundance of diazotrophic microorganisms in the South China Sea during intermonsoon. The ISME Journal, 2(9), 954-967. https://doi.org/10.1038/ismej.2008.51

Montoya, J. P., Voss, M., Kähler, P., \& Capone, D. G. (1996). A simple, high-precision, high-sensitivity tracer assay for $\mathrm{N}_{2}$ fixation. Applied and Environmental Microbiology, 62, 986-993.

Moore, C. M., Mills, M. M., Arrigo, K. R., Berman-Frank, I., Bopp, L., Boyd, P. W., et al. (2013). Processes and patterns of oceanic nutrient limitation. Nature Geoscience, 6(9), 701-710. https://doi.org/10.1038/ngeo1765

Moore, C. M., Mills, M. M., Achterberg, E. P., Geider, R. J., LaRoche, J., Lucas, M. I., et al. (2009). Large-scale distribution of Atlantic nitrogen fixation controlled by iron availability. Nature Geoscience, 2(12), 867-871. https://doi.org/10.1038/ngeo667

Mourino-Carballido, B., Grana, R., Fernandez, A., Bode, A., Varela, M., Dominguez, J. F., et al. (2011). Importance of $\mathrm{N}_{2}$ fixation vs. nitrate eddy diffusion along a latitudinal transect in the Atlantic Ocean. Limnology and Oceanography, 56(3), 999-1007. https://doi.org/10.4319/ lo.2011.56.3.0999

Mulholland, M. R., \& Bernhardt, P. W. (2005). The effect of growth rate, phosphorus concentration, and temperature on $\mathrm{N}_{2}$ fixation, carbon fixation. Limnology and Oceanography, 50, 839-849. https://doi.org/10.4319/lo.2005.50.3.0839

Mulholland, M. R., Bronk, D. A., \& Capone, D. G. (2004). Dinitrogen fixation and release of ammonium and dissolved organic nitrogen by Trichodesmium IMS101. Aquatic Microbial Ecology, 37, 85-94. https://doi.org/10.3354/ame037085

Olson, E. M., McGillicuddy, D. J., Flierl, G. R., Davis, C. S., Dyhrman, S. T., \& Waterbury, J. B. (2015). Mesoscale eddies and Trichodesmium spp. distributions in the southwestern North Atlantic. Journal of Geophysical Research: Oceans, 120, 4129-4150. https://doi.org/10.1002/ 2015JC010728

Rijkenberg, M. J. A., Langlois, R. J., Mills, M. M., Patey, M. D., Hill, P. G., Nielsdottir, M. C., et al. (2011). Environmental forcing of nitrogen fixation in the eastern tropical and sub-tropical North Atlantic Ocean. PLoS ONE, 6(12), e28989. https://doi.org/10.1371/journal. pone.0028989

Shiozaki, T., Bombar, D., Riemann, L., Sato, M., Hashihama, F., Kodama, T., et al. (2018). Linkage between dinitrogen fixation and primary production in the oligotrophic South Pacific Ocean. Global Biogeochemical Cycles, 32, 1028-1044. https://doi.org/10.1029/ 2017GB005869 
Shiozaki, T., Furuya, K., Kodama, T., Kitajima, S., Takeda, S., Takemura, T., \& Kanda, J. (2010). New estimation of $\mathrm{N}_{2}$ fixation in the western and central Pacific Ocean and its marginal seas. Global Biogeochemical Cycles, 24, GB1015. https://doi.org/10.1029/ 2009GB003620

Shiozaki, T., Kodama, T., \& Furuya, K. (2014). Large-scale impact of the island mass effect through nitrogen fixation in the western South Pacific Ocean. Geophysical Research Letters, 41, 2907-2913. https://doi.org/10.1002/2014GL059835

Shiozaki, T., Kodama, T., Kitajima, S., Sato, M., \& Furuya, K. (2013). Advective transport of diazotrophs and importance of their nitrogen fixation on new and primary production in the western Pacific warm pool. Limnology and Oceanography, 58(1), 49-60. https://doi.org/ 10.4319/lo.2013.58.1.0049

Shiozaki, T., Lee Chen, Y. L., Lin, Y. H., Taniuchi, Y., Sheu, D. S., Furuya, K., \& Chen, H. Y. (2014). Seasonal variations of unicellular diazotroph groups A and B, and Trichodesmium in the northern South China Sea and neighboring upstream Kuroshio Current. Continental Shelf Research, 80, 20-31. https://doi.org/10.1016/j.csr.2014.02.015

Shiozaki, T., Takeda, S., Itoh, S., Kodama, T., Liu, X., Hashihama, F., \& Furuya, K. (2015). Why is Trichodesmium abundant in the Kuroshio? Biogeosciences, 12(23), 6931-6943. https://doi.org/10.5194/bg-12-6931-2015.

Taboada, F. G., Gil, R. G., Höfer, J., Gomzález, S., \& Anadón, R. (2010). Trichodesmium spp. population structure in the eastern North Atlantic subtropical gyre. Deep Sea Research, 57(2010), 65-77. https://doi.org/10.1016/j.dsr.2009.09.005

Thompson, A., Carter, B. J., Turk-Kubo, K., Malfatti, F., Azam, F., \& Zehr, J. P. (2014). Genetic diversity of the unicellular nitrogen-fixing cyanobacteria UCYN-A and its prymnesiophyte host. Environmental Microbiology, 16(10), 3238-3249. https://doi.org/ $10.1111 / 1462-2920.12490$

Tripp, H. J., Bench, S. R., Turk, K. A., Foster, R. A., Desany, B. A., Niazi, F., et al. (2010). Metabolic streamlining in an open-ocean nitrogen-fixing cyanobacterium. Nature, 464(7285), 90-94. https://doi.org/10.1038/nature08786

Van Wambeke, F., Pfreundt, U., Barani, A., Berthelot, H., Moutin, T., Rodier, M., et al. (2016). Heterotrophic bacterial production and metabolic balance during the VAHINE mesocosm experiment in the New Caledonia lagoon. Biogeosciences, 13(11), 3187-3202. https://doi.org/10.5194/bg-13-3187-2016

Walsby, A. E. (1978). The properties and buoyancy-providing role of gas vacuoles in Trichodesmium Ehrenberg. British Phycological Journal, 13(2), 103-116. https://doi.org/10.1080/00071617800650121

Walsby, A. E., Kinsman, R., \& George, K. I. (1992). The measurement of gas vesicle volume and buoyant density in planktonic bacteria Journal of Microbiological Methods, 15(4), 293-309. https://doi.org/10.1016/0167-7012(92)90048-9

Wong, G. T. F., Chung, S. W., Shiah, F. K., Chen, C. C., Wen, L. S., \& Liu, K. K. (2015). Climate modulates internal wave activity in the Northern South China Sea. Geophysical Research Letters, 42, 831-838. https://doi.org/10.1002/2014GL062522

Wong, G. T. F., Tseng, C. M., Wen, L. S., \& Chung, S. W. (2007). Nutrient dynamics and N-anomaly at the SEATS station. Deep Sea Research, 54(14-15), 1528-1545. https://doi.org/10.1016/j.dsr2.2007.05.011

Wu, J., Chung, S. W., Wen, L. S., Liu, K. K., Lee Chen, Y. L., Chen, H. Y., \& Karl, D. M. (2003). Dissolved inorganic phosphorus, dissolved iron, and Trichodesmium in the oligotrophic South China Sea. Global Biogeochemical Cycles, 17(1), 1008. https://doi.org/10.1029/ 2002 gb001924.

Wu, K., Dai, M., Chen, J., Meng, F., Li, X., Liu, Z., et al. (2015). Dissolved organic carbon in the South China Sea and its exchange with the Western Pacific Ocean. Deep Sea Research, 122, 41-51. https://doi.org/10.1016/j.dsr2.2015.06.013

Xu, M. N., Zhang, W., Zhu, Y., Liu, L., Zheng, Z., Wan, X. S., et al. (2018). Enhanced ammonia oxidation caused by lateral Kuroshio intrusion in the boundary zone of the northern South China Sea. Geophysical Research Letters, 45, 6585-6593. https://doi.org/10.1029/ 2018GL077896

Yang, J. Y. T., Hsu, S. C., Dai, M., Hsiao, S. S. Y., \& Kao, S. J. (2014). Isotopic composition of water-soluble nitrate in bulk atmospheric deposition at Dongsha Island: Sources and implications of external N supply to the northern South China Sea. Biogeosciences, 11(7), 1833-1846. https://doi.org/10.5194/bg-11-1833-2014

Zhang, Y., Zhao, Z., Sun, J., \& Jiao, N. (2011). Diversity and distribution of diazotrophic communities in the South China Sea deep basin with mesoscale cyclonic eddy perturbations. FEMS Microbiology Ecology, 78(3), 417-427. https://doi.org/10.1111/j.1574-6941.2011.01174.x 